\title{
Framing Analysis of Edy Rahmayadi's News on MedanBisnisdaily.com
}

\author{
Anang Anas Azhar ${ }^{1,2}$, Daniel Pekuwali ${ }^{3}$ \\ ${ }^{1}$ Lecturer in Faculty of Social Sciences, State Islamic University of North Sumatera (UINSU), Medan, Indonesia \\ ${ }^{2}$ Lecturer in Postgraduate Program, Islamic University of North Sumatera (UINSU), Medan, Indonesia \\ ${ }^{3}$ Master Student in Postgraduate Communication Science, University of Muhammadiyah Sumatera Utara \\ (UMSU), Indonesia \\ email: anang_mb76@yahoo.com
}

\begin{abstract}
Mass media has an important role in imaging. Whether we realize it or not, the image is the result of mass media construction. The mass media can lift someone so that they become famous and supported by the community but can also bring down the person to become the most hated figure. The media constructs reality through certain points of view which are then framed or framed. In this study, the framing analysis of the Gamson and Modigliani models was used to find out how the reality or image of Edy Rahmayadi was constructed or framed by MedanBisnisdaily.com. According to Gamson, framing is a way of telling stories or clusters of organized ideas in such a way and presenting the construction of the meaning of events related to the object of a discourse. This type of research is qualitative with a constructivism paradigm. From this research, Medanbisnisdaily.com describes the image of Edy Rahmayadi as a firm, but controversial and seemingly arrogant person.
\end{abstract}

Keywords: politician image; framing analysis; reality construction; mass media; Edy Rahmayadi

\section{Introduction}

Facing the simultaneous local elections on June 27, 2018, political party leaders who participated in fighting for regional chair seats in a number of regions in Indonesia, including in North Sumatra (North Sumatra) began conducting campaign activities. Various approaches were taken, even before the official campaign period began. Various ways are used to build images, increase the popularity and elactability of each candidate.

Whether we realize it or not, the image is the result of mass media construction. The construction of reality in principle is telling, conceptualizing events, circumstances, and things. Every social actor plays a role in the construction process of this reality, including the mass media.

Mass media has an important role in imaging. Mass media can form certain images of an event or group and are understood as general truths in society. Symbols or terms that are continuously repeated create a separate image of something in the eyes of the community.

The media play a role in building a particular image or image of a political figure because of the role of the media in constructing reality. In this connection the media is a construction agent. The mass media can lift someone so that he becomes famous and supported by the community but he can also bring down the person so that he becomes the 
most hated figure. The media constructs reality through certain points of view which are then framed or framing.

Bimo Nugroho et al, in Silvana he said, theoretically, the mass media is not independent of political influence in determining the direction of the news. The device is used as a prism in the selection of the first is the political reality that is then encapsulated in media editorial policy in which the same reality can produce a different story construction. Then the response to market demands is called audience segmentation. In turn, this reader segment will affect the news.

In a constructionist view, the media is not just a free target, it is also a subject that constructs reality, complete with a biased and biased view. In the process of constructing reality, language is the main element. Language is a key instrument for telling reality. Language is a conceptualization tool and narrative tool. In addition, the ideology possessed by the journalist and the values he holds or adheres to will also influence the point of view taken when writing news about an event.

On Friday, January 18, 2018, the online news site Medanbisnisdaily.com contained news entitled "Edy Rahmayadi to Journalists: Don't Write What I Don't Say". This news was published a day after Edy Rahmayadi and Musa Rajekshah (Ijek), who at that time were still candidates for North Sumatra Governor and Deputy Governor for the period 2018-2023, underwent psychological tests at the Haji Adam Malik Hospital in Medan. This interesting news was analyzed because it became a very warm discussion among journalists in Medan, but not many media released it in the form of news.

In this study, framing analysis is used to find out how the reality or image of Edy Rahmayadi is constructed or framed by Medanbisnisdaily.com which views an event through certain glasses and labeling.

\section{Theoritical Framework}

\subsection{Construction of Mass Media Realities}

The term construction reality became famous since it was introduced by Peter L. Berger and Thomas Luckmann through his book The Social Construction of Reality: A Treatise in The Sociological of Knowledge (1996). He describes social processes through their actions and interactions, where individuals create continuously a reality that is shared and experienced together subjectively (Bungin, 2015: 13).

Social reality is everyday knowledge that lives like concepts, general awareness and public discourse as a result of social construction. According to McNair (1995) in Hasyim, an event, including a political event has three categories of reality, namely: First objective political reality, namely the reality displayed in accordance with what actually happened. Both are subjective political realities, namely the reality perceived by the public or political actors themselves. The three political realities are constructed, namely reality which is also subjective but covered through the media.

The media is essentially constructing reality. Media content is the result of media workers constructing the various realities that they choose, including political reality. The media content is essentially the result of the construction of reality with language as the basic 
device. Language is not only a tool to represent reality, but also can determine relief as to what language will be created about that reality. As a result, the mass media has a huge opportunity to influence the meaning and images produced from the reality constructed. In the mass media, the existence of language is no longer merely a tool to describe a reality, but can determine the image (image) that will appear in the minds of audiences.

Matteh Kieran in Eriyanto explained that news is not formed in a vacuum. News is produced from dominant ideologies in a particular area of competence. This socio-historical explanation helps explain how the world is systematized and reported in certain aspects of reality because the notion of reality is mediated by categories, interpretations and evaluations of reality.

Tuchman in Eriyanto said that news is the result of transactions between journalists and their sources. The main source of reality for news is not what is displayed or what happens in the real world. The reality of the news lies in nature and the type of social and cultural relationships that develop between journalists and their sources, and in the politics of knowledge that appears on each news beat.

\subsection{Image as Reality Construction}

Image is an interesting new term and is widely discussed today by many people. Image is something that is visible to the senses, but does not have a substantial existence, an equation or representation or visualization. Therefore he can refer to a visual representation and reality as seen in a photograph, he can refer to a mental conception, or imaginative of an individual, event, location or object.

According to Azhar, the image can be defined as the construction of the representation and perception of audiences towards individuals, groups or institutions related to their work in society.

Image construction in a news is usually prepared by the people who work in the editor of the mass media, ranging from journalists, editors, and editorial leaders. The construction of the image built by the mass media is formed in two models, namely the good news model and the bad news model. The good news model is a construction that tends to construct a report as good news. While the bad news model is a construction that tends to construct ugliness or give a bad image to the news object.

The use of language in mass media influences the construction of reality in the form of images because language contains meaning. Discourse plays a role in defining individuals and placing someone in a certain position. The media has a big role in that through the process of defining and marking so that representation is presented as natural, natural in reality.

Image/ image and media issues are two things that are closely related to each other, including in the realm of journalism. Here the image is defined as the construction of the representation and perception of the public (the public) of the individual about all matters related to activity, behavior and nature. The image reflects objective reality. An image also reflects things that are not real or an imagination that can sometimes be different from physical reality. Images can be created, built and strengthened. In addition, the image can also weaken, fade and disappear in the cognitive system of society. Images can also influence community judgment which leads to an action in the form of support.

\subsection{Framing Analysis}


The idea of framing was first put forward by Beterson in 1955. Initially the frame was interpreted as a conceptual structure or a set of beliefs that organized political views, policies and discourses and which provided standard categories to appreciate reality. But lately, the concept of framing has been used extensively in the communication science literature to describe the process of selecting and highlighting specific aspects of reality by the media. In the realm of communication studies, framing analysis represents a tradition that puts forward a multidisciplinary approach or perspective to analyze communication phenomena or activities.

In practice, framing analysis allows the inclusion of sociological, political and cultural concepts to analyze communication phenomena, so that a phenomenon can be truly understood and appreciated based on the sociological, political or cultural context that surrounds it. The concept of frames or framing itself is not purely derived from communication science, but from cognitive science (psychology). It is a method of empirical research and media content analysis techniques that are able to express media efforts to define social reality.

Frames are interpreted in various ways according to the object of study. In psychology, framing is a scheme while the scheme in the context of information science is an instrument of representation of knowledge. Sociologist Erving Goffman emphasizes that framing is a definition of the situation that is happening and answers the question what it is that going on here? In the context of political science, the frame is interpreted as a form of belief system as revealed by Gerhard/ Rucht as follows: We define a belief system as a configuration of ideas and attitudes in which the elements are bound together by some constraints.

Framing is simply framing an event. Framing is an approach to knowing how the perspective or perspective used by journalists when selecting issues and writing news. This perspective ultimately determines what facts are taken, which parts are highlighted and which parts are removed, and where to take the news. In framing analysis there are various models. For example framing analysis of Pan and M. Kosicki's models, William A. Gamson and Modigliani, Robert N. Entman, Murry Edelman and others. Framing analysis is the latest development that was born from the continuous elaboration of the discourse analysis approach.

\section{Research Methodology}

This study uses the framing analysis method of the Gamson and Modigliani models with the constructivism paradigm. This type of research is qualitative. According to Gamson, framing is a way of telling stories or clusters of organized ideas in such a way and presenting the construction of the meaning of events related to the object of a discourse. The way of storytelling is formed in a package (package) which includes a scheme or structure of understanding that is used by individuals to construct the meaning of the messages that they convey, and to interpret the meaning of the messages they receive.

In this package there are two structures, namely core frames and condensing symbols. The first structure is the center of the organization of ideas elements that help communicators to show the substance of the issue being discussed, while the second structure contains two sub-structures, namely framing devices and reasoning devices. As explained by Gamson, 
framing devices consist of methapor, exemplars, catchphrase, depicition and visual image. While reasoning devices include root (analyst clauses), consequencies (appeal) and appeal to principle (moral claims). Eriyanto simplifies the Gamson and Modigliani framing devices in Table 1.

Table 1. Framing of Gamson and Modigliani

\begin{tabular}{|c|c|}
\hline \begin{tabular}{c} 
Central organizing idea for making sense of relevant events, suggesting what is at issues. \\
\hline Framing Devices
\end{tabular} & Reasoning devices \\
\hline $\begin{array}{c}\text { Metaphors } \\
\text { Parables or presuppositions }\end{array}$ & $\begin{array}{c}\text { Roots } \\
\text { Causal or causal analysis }\end{array}$ \\
\hline $\begin{array}{c}\text { Exemplars } \\
\text { discourse. This is generally } \\
\text { in the form of jargon or slogan. }\end{array}$ & $\begin{array}{c}\text { Appeals to principle } \\
\text { Basic premise, moral claims }\end{array}$ \\
\hline $\begin{array}{c}\text { Link the frame to the example, description (can } \\
\text { be theory, comparison) that clarifies the frame }\end{array}$ & Effects or consequences obtained from the frame \\
\hline $\begin{array}{c}\text { Depiction } \\
\text { Depiction or depiction of a connotative issue. } \\
\text { Depiction is generally in the form of vocabulary, } \\
\text { lexicon for labeling something. }\end{array}$ & \\
\hline $\begin{array}{c}\text { Visual Images } \\
\text { Images, graphics, images that support the frame } \\
\text { as a whole. Can be in the form of photos, } \\
\text { cartoons, or graphics to emphasize or support the } \\
\text { message you want to convey. }\end{array}$ &
\end{tabular}

\section{Research Results And Discussion}

\subsection{Medanbisnisdaily.com Frame in Constructing Citra Edy Rahmayadi}

From the mapping using framing analysis, the construction of the news carried out by Medanbisnisdaily.com on the image of Edy Rahmayadi in the news "Edy Rahmayadi to Journalists: Don't Write What I Don't Say", can be seen from the following news frame table:

Table 2. Frame Structure of Medanbisnisdaily.com News about Edy Rahmayadi

\begin{tabular}{|c|c|}
\hline \multicolumn{2}{|c|}{ Frame } \\
\hline Framing Devices & Reasoning devices \\
\hline $\begin{array}{c}\text { Metaphors } \\
\text { Edy Rahmayadi claimed to be the most powerful } \\
\text { governor candidate in Indonesia because it was } \\
\text { supported by many political parties. }\end{array}$ & $\begin{array}{c}\text { Said Edy Rahmayadi who stated that journalists } \\
\text { are a group of people who are difficult not to } \\
\text { show the attitude of public officials. }\end{array}$ \\
\hline $\begin{array}{c}\text { Catchphrases } \\
\text { Edy: We agreed first. Don't write what I didn't } \\
\text { say. It's like making it up. }\end{array}$ & $\begin{array}{c}\text { Appeals to principle } \\
\text { The moral principle value in the news is } \\
\text { implicitly illustrating that what was said by Edy } \\
\text { Rahmayadi seemed to boast. }\end{array}$ \\
\hline
\end{tabular}




\begin{tabular}{|c|c|}
\hline $\begin{array}{c}\text { Exemplars } \\
\begin{array}{c}\text { Edy: I am supported by 60 seats in the DPRD, } \\
\text { while others are only 16. It's hard to find } \\
\text { additional. I throw 40 seats, I can still run for } \\
\text { office. }\end{array}\end{array}$ & $\begin{array}{c}\text { Consequences } \\
\text { The consequences of the news have a negative } \\
\text { impact on the image of Edy Rahmayadi. }\end{array}$ \\
\hline $\begin{array}{c}\text { Depion } \\
\text { Eding often said controversial statements. } \\
\text { Visual Images } \\
\text { Showing the side of closeness with the people and } \\
\text { firm. }\end{array}$ & \\
\hline
\end{tabular}

From the table frame of the Medanbisnisdaily.com news above, it emphasizes the character, credibility and reputation of Edy Rahmayadi as a candidate for North Sumatra Governor. In writing the news, Medanbisnisdaily.com explained in a straightforward statement from the main character resource person, Edy Rahmayadi.

The prominence of the firm image information owned by Edy Rahmayadi on this news is placed at the beginning of the news, namely on the headlines and news leads. News headlines are commonly used to show how journalists construct an issue, often by emphasizing certain meanings through the use of words that are branded and easily remembered by audiences.However, in this news writing, readers also seem to be led smoothly by using conjunctions that are useful to provide explanations and affirmations of the central frame that they want to build by providing measurable evidence of Edy Rahmayadi's reputation and character that often makes controversial and impressed statements. arrogant. This is clearly illustrated in the fifth paragraph to the end of the news. In the fifth paragraph, Medanbisnisdaily.com wrote that Edy claimed to be the most powerful governor candidate in Indonesia because it was supported by many political parties. According to him, there are no gubernatorial candidates who have greater support than him. Edy also briefly quipped Djarot Saiful Hidayat who was promoted by the PDI Perjuangan as an import candidate. He quipped the nomination process which had to go through several stages, such as; register, check health and so on. In this sentence, Edy was implicitly portrayed as a fictional figure and seemed to ignore the standard rules for the nomination of regional heads. In the last paragraph, Edy also mentions that journalists are a difficult group of people. Medanbisnisdaily quoted Edy's statement "You if it's not because it's hard not to come here." Indirectly, Medanbisnisdaily.com gave meaning to the statement that Edy had insulted the journalist profession.

Edy was also portrayed as a fictitious person who was inconsistent with the statement that had been made before. In the third paragraph, it was written, "But when asked to mention an example of media coverage that was not in accordance with his words, Edy was unable to explain. Even so when asked why he did not try to clarify media coverage which he said was inappropriate, retired three-star TNI AD general stated that there was no need."

\section{Conclusion}

From the framing analysis carried out, the researchers concluded that at the construction stage of the news, Medanbisnisdaily.com put more emphasis on the character or 
image of Edy Rahmayadi which was negative. In terms of event placement, Medanbisnisdaily.com places events as a marginal theme and is used as a news opener as a theme deliverer that describes the character or image of Edy Rahmayadi. While in journalistic practice, Medanbisnisdaily.com uses more key informants to reinforce the character and image of Edy Rahmayadi.

\section{References}

Azhar, Anang Anas. 2017. Komunikasi Politik untuk Pencitraan: Konsep, Strategi dan Pencitraan Politik. Medan: Perdana Publishing.

Bungin, Burhan. 2015. Konstruksi Sosial Media Massa. Jakarta: Prenadamedia Grup.

Eriyanto. 2002. Analisis Framing: Konstruksi, Ideologi, dan Politik Media. Yogyakarta: LKiS.

Garbner, George. 2007. Cultivation Analysis dalam West and Turner. Introducing Communication Theory. New York: McGraw Hill.

Hasyim, Nanang Mizwar. 2016. Konstruksi Citra Maskulinitas Calon Presiden (Study Analisis Framing Model Gamson Dan Modigliani Pada Pemberitaan Koran Harian Kompas Dan Jawa Pos Edisi Juni 2014). Yogyakarta: Jurnal Profetik Vol. 9 No. 1: $32-50$.

Karman. 2015. Konstruksi Realitas Sosial Sebagai Gerakan Pemikiran (Sebuah Telaah Teoretis terhadap Konstruksi Realitas Peter L. Berger). Jakarta: Jurnal Penelitian dan Pengembangan Komunikasi dan Informatika Vol. 5 No.3: 11-23.

Rakhmat, Jalaluddin. 2004. Psikologi Komunikasi. Bandung: Remaja Rosdakarya.

Silvana, Hana. 2013. Peran Media Massa pada Komunikasi Politik di Indonesia. Bandung: Jurnal JIPSI Vol.1 No.2: 15-40.

Sinambela, Debora Blandina. 2014. Konstruksi Berita Pengerusakan Lingkungan Kawasan Danau Toba oleh Perusahaan di Media Cetak. Analisis Framing Berita Pengerusakan Lingkungan Kawasan Danau Toba oleh PT Aqua Farm dan PT Allegrindo Nusantara di Harian Sinar Indonesia Baru. Medan: Jurnal KUPAS Hal. 56-68.

Sobur, Alex. 2015. Analisis Teks Media Suatu Pengantar Untuk Analisis Wacana, Analisis Semiotik, dan Analisis Framing. Bandung: PT Remaja Rosdakarya.

Wahyuni, Hermin Indah. 2008. Kecenderungan Framing Media Massa Indonesia Dalam Meliputi Bencana Sebagai Media Event. Jurnal Ilmu Sosial Dan Ilmu Politik, Vol. 11 No. 3:287-314. 